\title{
Assessment of Constraints and Opportunities of Honey Production in Gombora Haddiya Zone, South Nation Nationality and People Regional State, Ethiopia
}

\author{
Shukurala Chaimiso
Gombora District Livestock and Fishery Resource Development Office, South Nation Nationalities and People Regional State Ethiopia
*Correspondence: shukuralachaimiso@gmail.com

\begin{abstract}
The study was conducted in Gombora District, South nation national people regional state, Ethiopia to identify major beekeeping constraints and opportunities. Structured questionnaire was employed for the study. The study used interviews, surveys and visual observation as methods in looking for answer to research questions. Purposive and simple random sampling techniques were employed to select 180 beekeepers from two Peasants Association. The collected data were analyzed by using SPSS version 20. The result of the study exposed that the average amount of honey harvested /hive/year from traditional hive, transitional hive and modern hive were $8.22 \pm 0.042,13.83 \pm 1.05$ and $18.2 \pm 2.52$ respectively. The mean yield obtained from the three hives were statistically significant at $(\mathrm{p}<0.05)$. The most factors influencing honey pricing in the study area were distance from market ( $38 \%$ ), quality of honey $(20 \%)$, consumers' preference $(20 \%)$, color $(10 \%)$, and test of honey $(12 \%)$. The major constraints to beekeeping activity in the study area were: high cost of modern hives with accessories (1st), shortage of bee forage ( $2 \mathrm{nd}$ ), pests and predators (6rd, poising of bee colonies (4th), low quality of honey product (5th) and poor infrastruc ture development (3th). Regardless of the constraints encountered this sub sector; there are also future opportunities for beekeeping development in the District. These include; presence of huge number of bee colonies, progressively increasing the demand of local honey, presence of beekeepers association and presence of good government policy. The study exposed that the price of honey in the study area is influenced by quality of honey, color, consumers' preference, distance from market and test of honey. Extra study is required to evaluation of honey quality in study area; characterize honey beekeeping practice in the study area and major pests, predators and disease of economic importance.
\end{abstract}

Keywords: honey bee, honey, constraints of beekeeping

\section{Introduction}

Ethiopia is a leading honey producer in Africa and one of the ten largest honey producing countries in the world. Ethiopia has a share of around $23.58 \%$ and $2.13 \%$ of the total Africa and world honey production respectively ${ }^{[1]}$. Due to its wide climatic and edaphic variability, Ethiopia is a home to some of the most diverse flora and fauna in Africa that provide surplus nectar and pollen source to foraging bee colonies ${ }^{[7]}$. This assisted to exist more than 12 million honey bee colonies in the country ${ }^{[6]}$. Despite the favorable agro ecology for honey production and the number of bee colonies the country is endowed with, the level of honey production and productivity in the country is remain low. One of the prominent factors for this low honey and productivity is traditional hives. Ethiopia has the potential to produce 500,000 tonnes of honey per year and 50,000 tonnes of beeswax per annual, but currently production is limited to 43,000 tonnes of honey and 3,000 tonnes of beeswax ${ }^{[11]}$. The quantity and quality of Ethiopian honey in generally poor, as 95\% of beekeepers follow traditional method of beekeeping practice with no improved techniques of technology ${ }^{[12]}$.

Ethiopia has huge natural resources for beekeeping activity. However, like any other livestock sector, this sub Sector has been seriously devastated by complicated constraints. The current production constraints in the beekeeping sub sector of the country would vary depending on the agro ecology of the areas where the activities is carried out [2]; [14]. The major constraints that affect beekeeping sub-sector in Ethiopia are: lack of beekeeping knowledge, shortage of skilled man power, shortage of bee equipments, pests and predators, pesticide threat, poor infrastructure development, shortage of bee forage and lack of research extension ${ }^{[8]}$.

Gombora, district has potential for beekeeping activities because relatively the area is coved with high natural resource and thus in the district's apiculture resource is huge. 
According to the head of Gombora, district livestock and fishery resource development office, there are a total of
What is the current potential of honey production in Gombora district?

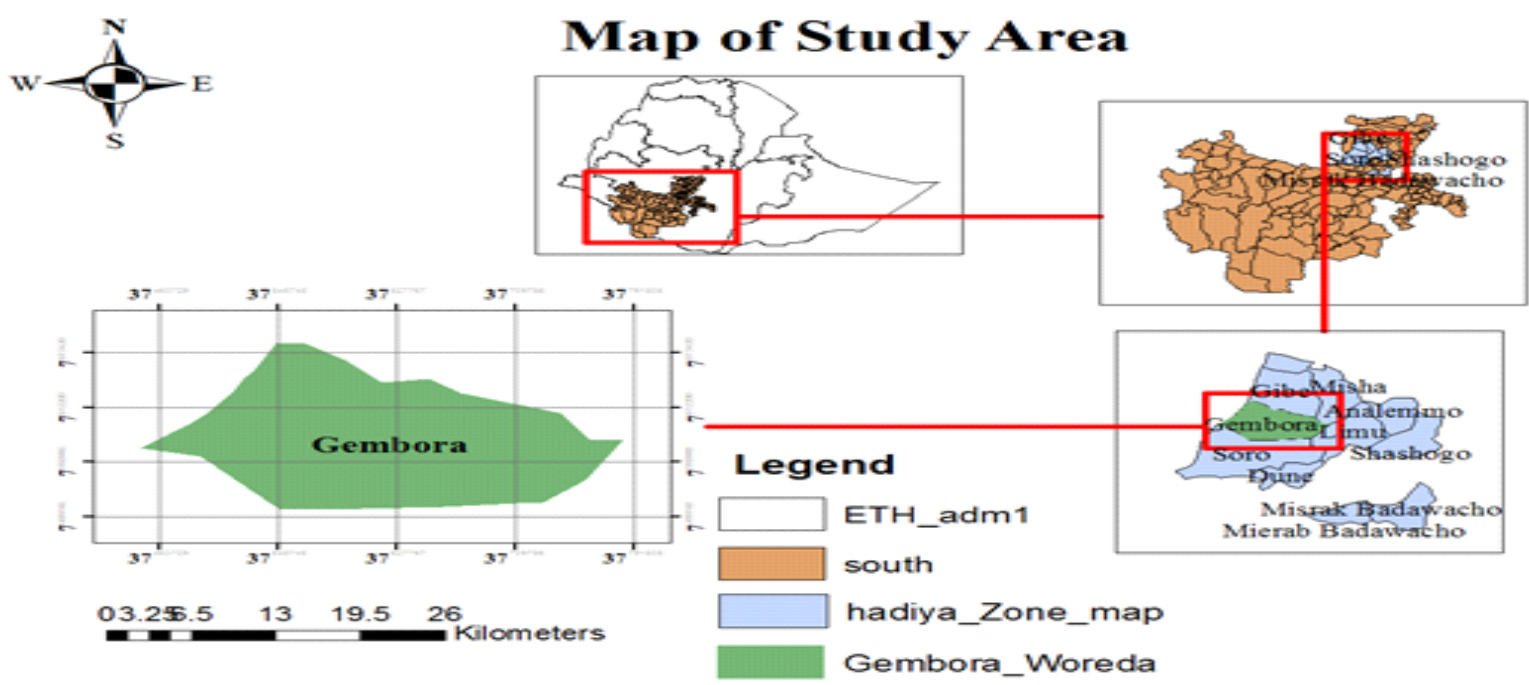

Figure 1. Map of study area

14488( about 9763 traditional bee hives, 716 transitional hives and 4009 modern) hives in the district. Even though, Gombora, district has huge number of bee colonies, farmers cannot get the benefit they should get from beekeeping subsector because of more than $89 \%$ beekeepers follow the traditional method of beekeeping. This contributes to lowl. yield and quality of bee products. Low productivity and quality of bee products are the major economic obstacle for beekeepers [10]. Depending on these truths, even though apiculture resource is vast in the district, there is no research information regarding to honey production potential, evaluation of honey quality, beekeeping constraints and the exits opportunities for future, in the district which is very essential to identify the potential development constraints. Therefore, General objective of this research conducted to exploit the major beekeeping constraints and accessible opportunities in the Gombora district in south nation nationality and people's regional state of Ethiopia.

Specific objectives of the study was

To assess the constraints that affecting beekeeping development in Gombora district.

To assess the current potential of honey production in Gombora district.

To assess opportunities for beekeeping development in the Gombora district.

\section{Research questions}

What are the constraints that affecting beekeeping development in Gombora district?
What are the opportunities of honey production in the study area?

What are the market constraints that affect honey production in the study area

\section{Materials and Methods}

\subsection{Description of the study area}

The study will be conducted in Gombora District of Haddiya Zone, Southern Nations, Nationalities and Peoples Regional state (SNNPRS) of Ethiopia. Gombora District is located about $259 \mathrm{~km}$ South of Addis Ababa and $27 \mathrm{~km}$ away from Hossana, the capital of Haddiya Zone and it is one of the 11district of Haddiya Zone. It is geographically located between $7049^{\prime} 27^{\prime \prime} \mathrm{N}$ latitude and 370 45' 35" E longitudes (Figure 1). Gombora District is bordered in the North by Gibe District, in the North East by the Misha District, and on the South Soro District, in the East by the Limo District, and in the West by Omo River Yam special District and Oromiya Regional States. This District has 22 rural villages and 2 urban towns. The administrative center of this District is Habicho; other town in Gombora district includes Bushana [13].

\subsection{Methods of data collection}

Before conducting field survey research, discussion was conducted with the head of Gombora district of livestock and fishery resource development office and bee expert to select sites and respondents. Based on the information of district livestock and fishery resource development office and bee expert, 180 beekeepers were purposively selected from two 
PAs to collect the required information. The interview was conducted with the selected respondents to generate the significant data by using structured questionnaire survey and check list. Visual observation was also part of data collection.

\subsection{Method of data analysis}

Primary data such as socio-economic characteristic of respondents, numbers of bee colonies, honey production potential, beekeeping constraints were collected through structured questionnaire. The collected data were analyzed using appropriate statistical packages for social sciences (SPSS) software version 20. Moreover, position of beekeeping constraints was used to identify and prioritize the major beekeeping challenges to beekeeping development in the study district. On the other hand, data collected through interview were analyzed through telling and explanation.

\section{Results and Discussion}

4.1. Demographic characteristic of the respondents Demographic characteristic of the respondents with structured questionnaire survey during field work are presented in the following section.

\subsubsection{Sex of the respondents}

Out of the total respondents, about $96 \%$ of the interviewed small scale beekeepers involved in honey value chain is male, whereas $4 \%$ involved in honey value chain are female. The survey result indicates that beekeeping activity in the study area is dominated by male. In the district beekeeping activity is mostly practiced with the traditional method of honey production by using local bee hives. The traditional hives are hanging on big tree branches in which some of trees are as long as 35 meters and above. Female cannot climb up such big trees to do beekeeping activity and as a result female are not confident to participate in beekeeping activity. Thus beekeeping is traditionally male dominated in the Gombora district.

\subsubsection{Age of the respondents}

Beekeepers who involved in honey production had an average age of 38 years old. The survey result showed that farmers in the most productive age are actively engaged in beekeeping activities with the average experience of 8.9 years. The mean land holding per the respondents' household was estimated to be 1.25 ha.

\subsubsection{Religion of the respondents}

Regarding to the religion of respondents, about $97 \%$ are protestant, $2.5 \%$ Catholic Church followers and $0.5 \%$ orthodox. The survey result indicates that protestant religion is the most dominate religion in the study district.

\subsubsection{Family size of the respondents}

The beekeepers that have different family size were occupied in beekeeping activity. The minimum and maximum family sizes of the respondents were 4 and 12 respectively.

\subsubsection{Educational background of the respondents}

Out of the total interviewed about $60 \%$ and $33 \%$ of the respondent beekeepers have attended primary and secondary school respectively. The rest about $7 \%$ respondents were illiterate or who cannot read and write.

\subsection{Honey production development}

Ethiopia is the leading honey and wax producers worldwide for centuries. Ethiopia produce about $98 \%$ of it's from traditional hives ${ }^{[4]}$. For many farmers, beekeeping is one of their major activities in addition to livestock keeping and agriculture. Out of the total respondents, about $77 \%$ beekeepers were replied that honey yield in the district is decreasing over the years as a result of forest deforestation, agrochemical application, pests and predators attack. The rest $23 \%$ respondents were replied that honey yield in the district is varies from time to time related to season. When rain fall season is good, there is sufficient pollen and nectar source of bee forage in the area. The amount of honey produced in such season is high but if the dry season prolonged, there is shortage of bee forage availability in the area. In this season, the amount of honey harvested is very low.

Most of the respondents replied that honey is collected at end of rain season between October and November. From the total interviewed farmers, about $37 \%$ were harvesting honey only once time per year. It was observed that most of these beekeepers were used traditional hives for honey production. The reaming $63 \%$ of the respondents were harvesting honey twice per year. These respondents were able to harvest honey twice per year because of they are practicing provision of supplementary feed for their bee colonies during the dry season and also follow seasonal colony management practice. According to the interviewed beekeepers and the district bee expert, there are three types of bee hives beekeepers use for honey production in the district. The survey result exposed that, the average amount of honey harvested per hive per year in district from traditional, transitional and modern hive was $8 \mathrm{~kg}, 13 \mathrm{~kg}$ and $19 \mathrm{~kg}$ respectively.

\subsection{Honey marketing}

Beekeepers of the study area sell their honey at different places and have different costumers. Sample respondents who produce and sell honey were asked their main customers. 
Table 1. Honey yield from traditional, transitional and modern hives in $\mathrm{kg}$ per year of the study area

\begin{tabular}{llll}
\hline No & Types of hives & Districts & $\begin{array}{l}\text { Mean } \\
\text { 土standard } \\
\text { deviation }\end{array}$ \\
\hline $\mathbf{1}$ & Traditional hive & Gombora & $8.22 \pm 0.042^{\mathrm{a}}$ \\
$\mathbf{2}$ & Transitional hive & Gombora & $13.83 \pm 1.05^{\mathrm{b}}$ \\
$\mathbf{3}$ & Modern hive & Gombora & $18.2 \pm 2.52^{\mathrm{c}}$ \\
\hline \multicolumn{2}{l}{ The mean in table having different superscript are show }
\end{tabular}

Accordingly, they mostly sell their honey to local honey traders $37.8 \%$, Gombora beekeepers association $48 \%$ and local honey consumers $14.2 \%$. According to the survey result and secondary data obtained from the district livestock and fishery resource development office, the price of honey is in the study area subjected to price fluctuation with the highest price in the dry seasons, especially during the wedding time from January to April and in wet seasons from June to August, the period when there is limited honey production. The lowest price is during honey harvesting time from October to November. Beekeepers sell the largest proportion of their honey during harvest at low price mainly to meet their demand for cash to pay taxes, debts and other social obligation [3]. According to the interviewed farmers, the price of honey is also governed by different factors such as distance from market $38 \%$, quality of honey $20 \%$, consumers' preference $25 \%$, color of honey $10 \%$, and test of honey $12 \%$.

\subsection{Constraints of honey production in the Gombora district}

Ethiopia has huge natural resource for beekeeping activity. However, like any other live stock, this sub sector has been influenced by complicated constraints. The existing production constraints in the beekeeping sub sector of the country would vary depending on the agro ecology of the areas where the activities is carried out ${ }^{[2] ; ~[14] . ~ T h e ~ i n t e r v i e w e d ~}$ beekeepers were mentioned the major beekeeping constraints in the district are: low quality of honey product, high cost of modern bee equipments and accessories, shortage of bee forage, problem of agrochemicals, problem of pests and predators and poor infrastructure development. This result agrees with report of [8] 'shortage of bee forage', 'threat of pesticide, 'honeybee pest and predators', poor infrastructure development, 'shortage of bee equipments which were reported as the major beekeeping constraints in Amhara regional state.

\subsubsection{Low quality of honey product}

Inadequate of production knowledge and poor post-harvest handling system often results in poor of honey quality.
Excessive using smoking materials during honey harvesting and inappropriate storage containers are the main problems in honey quality. Since honey producers have limited knowledge of the preference of their target market, they do not want to improve the quality of their honey. Low productivity and quality of bee products are the major economic obstacle for beekeepers [10]. Honey is almost exclusively used for local consumption mainly for the brewing of mead also called Tej, even though the national honey production satisfies the local demand it is so crude that it could not compete in the international market. Even though the demand of table honey is increasing at national level, farmers 'product quality doesn't fit into that market and hence they are forced to sell their yield locally to traders at prices much lower than in national commercial market ${ }^{[7]}$.

Marketing of honey is not a big problem in the study area because honey produced is sold at village level mainly for wedding ceremony, cultural cerebrations and medicinal purposes. Farmers also sell their honey to middle man, local brewer makers and tourists. Most of beekeepers in Gombora district are using traditional bee hives for honey production. About $85 \%$ honey was harvested from traditional hives. Traditional hives are not appropriate during honey harvesting because it is hang on big tree trunk and honey is harvested during the night. Pollen, bee brood and honey combs were removed together of honey and kept in the same containers. Such honey is containing large proportion of impurities. After they harvested honey, only few beekeepers strain their honey before sell by using honey extractor, nylon clothes, and hand. The farmers who do not strain honey reported that they lacked knowledge of staring as well as materials.

\subsubsection{High cost of modern bee hives and accessories}

The interviewed beekeepers responded during the field survey that some of the bee equipments such as modern bee hives, wax printers and honey extractors are very expensive and thus farmers could not cheap to buy and use these equipments. Currently, the cost of one modern bee hive ranges from 13001800 Ethiopia birr, the cost of honey extractor is ranges 700011,000 Ethiopian birr and the cost of wax printer is ranges from 10,000-13,000 ETB. As a result of these, there is a shortage of appropriate technologies for production, collection, processing, packing and storage in the area. The interviewed beekeeper stated that, improved bee equipments to the district farmers are beyond their buying capacity and even is not easily available for those beekeepers who are afford to buy it. The participants also indicated that there is no microfinance institutions that financing or provide credit services for those farmers who want to invest in modern honey production in the district. Most of the district farmers were resource poor and thus they are unable to buy and use modern bee technologies to improve honey yield.

\subsubsection{Pests and predators}


Ethiopia, as one of the sub-tropical countries, the land is not only favorable to bees, but also for different kinds of honey bee pests and predators that are interacting with the life of honey bees ${ }^{[6]}$. Pests and predators cause a serious shocking damage on honey bee colonies with in short period of time and even over night. The interviewed beekeepers were stated the major bee pests and predators in the district were: spider, ants, Bee-eater birds, honey badger and insect are the most of the problems to beekeeping development. This result agrees with the report of ${ }^{[15]}$, ants, honey badger, bee-eater birds, wax moth, spider, and beetles were the most harmful pests and predators in order to decreasing importance of beekeeping in Amhara region.

\subsubsection{Shortage of bee forage}

According to the interviewed beekeepers, this problem is directly related with deforestation of forest coverage from time to time for timber making, construction, fire wood and expansion of agricultural lands. These are cause shortage of bee forage especially during the dry season. Few beekeepers of the district have been migrating their bee colonies from their area to other area during the dry season for searching bee forage. This will increase the expense of farmers in the form of wage and cause colony loss through pests and predators. The elimination of good nectar and pollen producing tree species in many areas make it difficult to maintain bee colonies without feeding ${ }^{[15]}$. Due to deforestation and poising of agro-chemicals, the honey bee population is in state of continues declining. As a result, it has become a serious challenge to get honey bee colonies to start and expand beekeeping [13]. Beekeeping sector is dependent on healthy flora and a healthy environment. Recent years have seen environmental changes in Ethiopia in terms of irregular rain fall patterns and deforestation. If these problems worsen, the beekeeping sector could be affected ${ }^{[12]}$.

\subsubsection{Problems of agrochemical}

The district farmers are producing mainly wheat, barley, teff, pea, bean and different horticultural crops. They use chemical spray such as pesticide and herbicide for pesticides and weed controlling without considering damage it cause on bee colonies. The interviewed farmers stated that a number of bee colonies either die or absconded from their hive due to extensive use of agro-chemical in the district. The chemical spray used by district farmers is also destroying bee forage like herbs and shrubs which is used as sources of bee forage. The use of pesticides that kill bees and herbicides are not toxic to bee colonies but destroy many plants that are valuable to bees as sources of pollen and nectar such as Malathion, sevin, DDT, 2-4 and Acetone ${ }^{[8]}$. Insecticides have more devastate effect on bee colonies compare to herbicides. To overcome these problems $28 \%$ of respondents use chemical far from apiary site, $0.5 \%$ use hand weeding, $4 \%$ adjust time of chemical application, $4 \%$ close hive entrance during chemical spraying and 63.5 do not use any control measure for chemical application.

\subsubsection{Poor Infustructure development}

The availability of infrastructure in the district is very poor compared to others zone districts. There are no rural roads that connect different peasant association to the main town of district. The local market far away from the farmers and the transportation is not accessible. Beekeepers were traveled an average $28 \mathrm{~km}$ and expensed an average 17 Ethiopian birr for transport cost to sell their honey at local market. In the district, information technology such as telecommunication is not widely developed to share information with each other regarding to the price of honey. Smallholder farmers lack organization and access to communication and this gives market players a negative picture of their strengths and credibility ${ }^{[12]}$.

Table 2. Major constraints of beekeeping in the study

\begin{tabular}{lll}
\multicolumn{2}{c}{ area } & \\
\hline Constraints & $\begin{array}{l}\text { \% of } \\
\text { respondents }\end{array}$ & Rank \\
\hline $\begin{array}{l}\text { High cost of modern hives } \\
\text { and accessories }\end{array}$ & 34.3 & 1 \\
$\begin{array}{l}\text { Shortage of bee forage } \\
\text { Pests and predators }\end{array}$ & 21.6 & 2 \\
$\begin{array}{l}\text { Posing of agrochemical } \\
\text { Low quality of honey }\end{array}$ & 14.4 & 6 \\
product & 8.2 & 4 \\
$\begin{array}{l}\text { Poor infrastructure } \\
\text { development }\end{array}$ & 16.2 & 5 \\
\hline
\end{tabular}

4.5. Opportunities of honey production in the study area Although there are many constraints in the study area, there are also opportunities for future honey production improvement in the study area. According to the interviewed beekeepers, the major opportunities for beekeeping development are:

\subsubsection{Presence of huge number of bee colonies}

According to the Gombora district bee experts; there are a total of 14488(about 9763 traditional, 716 transitional and 4009 modern bee hives) in the district. The availability of these huge number of bee colonies in the area will give great opportunities for the district beekeepers for those who want to expand and produce more honey in the future.

\subsubsection{High demand for local honey from honey traders and consumers}

The consumption of honey increase with the income of people. Currently, the incomes of local people have been improving and the demand for honey consumption is also 
increasing. These in turn will create good opportunities and hope in the future for those beekeepers living in the area to expand beekeeping activities.

\subsubsection{Closeness of the area to big city and towns}

Gombora district is close to big towns such as Hossana, Gimbichu and Jajura. Beekeepers that produce honey easily can take and sell their honey in these towns. This will create good market for the district beekeepers to sell their honey.

\subsubsection{Presence of Gombora beekeepers association in the area}

Gombora beekeepers association was established in 2001 by 32 local beekeepers in Gombora district with the support of Catholic religion followers from Itally. Currently, the association has about 275 members who are involved in honey producing, collecting, processing, packing, labeling and sold processed honey in glass labeled jars in the national and international market. The main objectives of the establishment were to help the local beekeepers to rationalize honey production, improve honey quality, to create market linkage honey product, to improve the income of the beekeepers and to conserve and protect the surrounding forest though integration of beekeeping with natural resource conservation. Hence, the establishment of Gombora(Shalala) beekeepers' association in the district was created good market center for the surrounding beekeepers because the association collect their honey and combine them to other potential honey buyers.

\subsubsection{Presence of good government policy}

Beekeeping is one of the most important income diversify activities in the rural communities especially for those land and jobless people. Many resource poor people sell their honey to domestic markets and utilized income to purchase livestock, agricultural inputs, food crops, clothe for their children and pay land tax. Currently, the government is gives strong emphasis than ever before to beekeeping sub sector to use beekeeping practice as a tool for poverty reduction and to diversify the national export.

\section{Conclusions}

From the survey result it is concluded that modern and transitional hives give more honey production annual (18.2 \pm 2.52 and $13.83 \pm 1.05 \mathrm{~kg} /$ hive respectively) when compared to traditional hive $(8.22 \pm 0.042 \mathrm{~kg})$. The major factors governed price of honey in the study area were distance from market, quality of honey, consumers' preference, color of honey, and test of honey. The most important constraints to honey production in the study area were high cost of modern bee equipments and accessories, shortage of bee forage, pests and predators, poising of bee colonies, low quality of honey products and poor infrastructure development. Regardless of different constraints encountered this activity in the study area, the opportunities for beekeeping development include: presence of huge numbers of bee colonies, high demand for local honey from local honey traders and consumers, closeness of the area to big towns, availability of Gombora beekeepers association in the area and presence of good government policy. The study revealed that the price of honey in the study area is governed by different factors including: quality of honey, color, consumers' preference and distance from market and test of honey. Thus, further study is required to evaluation of honey quality, assess the beekeeping practice in the area and characterize honey bees of the area, and major pests, predators and disease of economic importance.

\section{References}

[1]. K. Ayalew, "The honey bees (Apis mellifera) of Ethiopia. Amorphometric study," M.Sc thesis, Agricultural University of Norway, Norway, 1990.

[2]. K. Ayalew, "Beekeeping manual. Agri-Service Ethiopia, Addis Ababa Countries,' Lynne Rienner Publishers, Boulder, and London: p. 57, 1994.

[3]. T. Beyene, and P. David, "Paper prepared for International Development Enterprises (IDE) and Ethiopian Society for Appropriate Technology (ESAT)',, 2007.

[4]. Central Statistical Agency, "Agricultural sample survey," Volume II report on: Livestock and Livestock Characteristics, Central Statistical Agency, Addis Ababa, Ethiopia, 2007.

[5]. B. Desalegn, "some major pests and predators of honeybees in Ethiopia. Proceedings of the 3rd National Annual Conference of Ethiopian Beekeepers Association.' Addis Ababa, Ethiopia, September 3- 4 (2001), pp 59-67, 2001.

[6]. T. Gezahegne, "Marketing of honey and beeswax in Ethiopia: past, present and perspective futures'. Proceedings of the 3rd National Annual Conference of Ethiopian Beekeepers Association, September 34 (2001), Addis Ababa, Ethiopia, pp 78-88, 2001.

[7]. D. Girma, "Non-Wood Forest Production in Ethiopia. Addis Ababa, Ethiopia,', http://www.fao.org/DOCREP/003/X6690E/X6690 E00.htm, 1998.

[8]. E. Kerealem, G. Tilahun and T.R.Preston, "Constraints and prospects for apiculture research and development in Amhara region, Ethiopia,", http://www.lrrd.org//rrd21/10/ejig21172.htm date accessed February, 2009.

[9]. Nuru, "Quality state of grading Ethiopian honey," In: Proceedings of the First National Conference of 
the Ethiopian Beekeepers Association, Addis Ababa, Ethiopia, 1999.

[10]. "Ministry of Agriculture and Rural Development (MOARD), Government of Ethiopia," Addis Ababa Ethiopia, December 2008.

[11]. Oxfam Partner Progress Report, "The honey produced in traditional hives is often mixed with wax, pollen, dead bees, and extraneous matter," This means that it cannot be used for processing or for export as table honey, but is only suitable for use in tej brewing, Addis Ababa, Ethiopia," 2008.

[12]. Nuru, "Atlas of Pollen Grains of major honeybee flora of Ethiopia, Holeta, Ethiopa," Holeta Bee Research Centre, 2007.

[13]. Zenebe, "Farmers awareness about land degradation and the Practices of soil and water conservation measures in Haddiya zone," the Case of duna woreda, Ethiopia (Doctoral dissertation), 2015.

[14]. N. Edessa, 'Survey on honey production system in West Shoa Zone," Holeta Bee Research Center (HBRC), Ethiopia, 2002.

[15]. E. Keralem, "Honey bee production system, opportunities and challenges in Enebse Sar Midir Woreda (Amhara Region) and Amaro Special Wereda (Southern Nations, Nationalities and peoples Region), Ethiopia," M.Sc. thesis presented to Alemaya University 133p, 2005. 